\title{
Economic Impacts of the Vale-Cultura (Culture Voucher): A Computable General Equilibrium Model
}

\author{
Gustavo Fernandes Souza, Ana Flávia Machado, Edson Paulo Domingues \\ Centro de Desenvolvimento e Planejamento Regional (CEDEPLAR), Federal University of Minas Gerais, Belo Horizonte, Brazil \\ Email: gfsouza.ecn@gmail.com, afmachad@cedeplar.ufmg.br, epdomin@cedeplar.ufmg.br
}

How to cite this paper: Souza, G.F., Machado, A. and Domingues, E.P. (2019) Economic Impacts of the Vale-Cultura (Culture Voucher): A Computable General Equilibrium Model. Theoretical Economics Letters, 9, 1411-1433.

https://doi.org/10.4236/tel.2019.95091

Received: April 15, 2019

Accepted: June 14, 2019

Published: June 17, 2019

Copyright $\odot 2019$ by author(s) and Scientific Research Publishing Inc. This work is licensed under the Creative Commons Attribution International License (CC BY 4.0).

http://creativecommons.org/licenses/by/4.0/

\begin{abstract}
The aim of this study is to analyze the impacts of the voucher system Vale-Cultura in the Brazilian cultural sector and in the economy in general. The methodology applied is the Brazilian Recursive Dynamic General Equilibrium model (BRIDGE). Our simulations found that GDP growth is driven mainly by the increase in household consumption. There is a positive variation in welfare, assessed by the equivalent and compensating variations in income for beneficiaries of the vouchers. Indirect and production taxes are positively affected because of the various effects on the economy, which partly makes up for the government transfers to companies via tax waiver. Finally, a positive growth is projected at the level of activity of cultural sectors and negative growth in others, showing a reallocation of productive factors.
\end{abstract}

\section{Keywords}

Culture, Vale-Cultura, CGE, Impacts, Consumption, Well-Being, Sectoral Analysis

\section{Introduction}

The importance of the cultural sector to socio-economic development is a recurring theme in economic literature, mainly in regional economic studies and public policy analysis. A particularly relevant discussion is the transversal nature of the cultural sector, which is associated with diversity in terms of production and distribution methods.

It is understood that, due to this transversal nature, growth in the cultural sector could create spillover benefits into other productive chains, which would bring a virtuous effect for the economy. Due to these net benefits, consumption 
of cultural goods and services should be encouraged with public policies.

In Brazil, access to cultural goods and services is one of its major problems ${ }^{1}$, due to individual, social or economic constraints. The government is aware of this problem and it tries, through public policies, to reduce the gap between its potential consumers. One of the most recent policies in this regard is the Programa Cultura do Trabalhador (Culture for the Worker Program), which established a voucher system known as Vale-Cultura, in which individuals eligible for the program receive an income transfer to be used exclusively for the purchase of cultural goods and services, from a previously government-defined list.

The objective of this work is to study increased expenditure in cultural goods and services by the workers eligible to Programa Cultura do Trabalhador through a simulated positive income shock. We study the impacts of this simulated shock in individuals residing in the urban space of the nine main Brazilian metropolitan regions. The predictions are made through an applied general equilibrium model and encompass both aggregated and sectorial effects. It is the first study that seeks to analyze the economic impacts of Vale-Cultura, and one of the pioneers uses a CGE model for the cultural sector rather than the input-output model in Brazil. In the CGE simulations, the capital stock grows over time and the labor market presents some sluggishness in the adjustments of wages and employment.

\section{Policies to Encourage Access to Culture}

\subsection{Cultural Sector and Regional Development}

The cultural sector is defined as a set of goods and services that includes artistic creativity in its production ${ }^{2}$. Examples of activities in this sector include crafts, theatre plays, video games, movies in general, among others.

The cycles of creation, production, distribution and consumption of various cultural goods and services have significant differences and include activities from manufacturing industry, commerce and services. The distribution process of a piece of handicraft, for example, depends mainly on the logistics of the transport system. Regarding digital movies and music, the speed of the broadband connection is the major factor affecting distribution efficiency. This heterogeneity is also reflected in the competitive market, with its various coexisting structures, from large oligopolies such as those in the film industry, to a competitive market centered around small autonomous production, as seen in artisanal production.

According to Bille and Schulze [5], the impacts of the cultural sector on regional development can be divided into short-term and long-term. In the short term, attracting tourists has great importance, both for the local and non-local perspective; whereas long-term effects would be related to attracting permanent residents, companies and investments.

${ }^{1}$ This subject is discussed in [1] [2] and [3].

${ }^{2}$ There are other definitions to the term "culture" that permeate the economic context, which are dealt with in this article [4] [5]. 
The production process is usually concentrated in major urban centers due to the advantages of urban agglomeration. The proximity from both the consumer market as well as other producers reflects the positive externalities of production and consumption in economies of scale and scope [5], and this leads to the creation of cultural districts. According to Santagata [6], cultural districts are a good example of economic development based on industrial location and local culture, and this aspect is positive in several ways: job creation, income generation, intergenerational transmission of creativity, among others. According to Singh [7], FDI helps to bring development from one region to another one and promote growth.

In theoretical terms, a cultural district is result of the confluence of two phenomena: localization and the idiosyncratic nature of culture. Alfred Marshall [8], pioneer of industrial localization studies, suggested that industrial districts are generally based in external agglomeration economies. Amongst the advantages of industrial agglomeration there would be free diffusion of ideas and information, creation of markets for capacitated workers and dissemination of innovations. From the point of view of consumption, Marshall observed that consumers are willing to travel great distances if they find a demanded product with greater availability and lower prices. Thanks to industrial agglomeration, the average production and transaction costs can decrease, creating inner economies of scale. Thus, concerning cultural districts, these would present a lower market cost than any other place thanks to intense creation of positive externalities, such as tacit knowledge, high innovation rate and zero cost for information diffusion.

Yet, concerning positive externalities, Santagata [6] identified two types. The first is called "atelier effect", related to labor market demand. There are individuals more capacitated for professional cultural activities in industrial districts than the amount demanded by the labor market, which stimulates creative and innovative initiatives, as well as their market differentiation. Besides, the combination between culture and digitalization of many economic processes allow aggregation of value in industrial products, such as design remodeling, access to digital platforms, among others.

Another argument is proposed by Markusen [9], which emphasizes the importance of consumption to induce regional development. She named it Theory of Baseline Consumption. According to her, many services, such as medical assistance and artistic performance, are heavily intensive in labor, so that great part of money spent in these activities returns to the assets of the population in form of taxes. This results in a multiplier effect in the economy greater than, for example, expenditure in imported goods in malls. Further, the growth of total employment does not depend only on export-related employment, but also from the consumption-related one, which represents an addition to the Keynesian multiplier used in traditional export models. Many of the goods classified as cultural ones are intensive in labor and, besides, upon offering entertainment to the population, they incentivize expenditure in local goods and inhibit in imported ones, besides attracting tourists and retirees, which stimulates local de- 
velopment in the long run. Investing in culture, for this reason, would make the territory more attractive for fixing residence, besides turning it into an option for business tourism.

The cultural sector can also create growth in other sectors through its linkages. The concepts of forward and backward linkage effects were developed by Hirschman [10] in his Theory of Unbalanced Growth ${ }^{3}$ and are related to the potential for promoting new productive investments. Backward effects occur from increased demand for inputs from other sectors. They express externalities from the implementation of industries that would make possible a minimum viable scale of production in certain places when there is an increase in demand in the forward sector. Therefore, they would encourage input suppliers to find new productive investments. Forward effects are characterized by increased final demand in each of the productive sectors, which causes an increase in the production of a particular product, favoring forward sectors. The result is a strong source of growth-inducing effects on the economy.

An example would be the phonographic industry. A petrochemical plant can produce acrylics and aluminum to use in CDs, which are then used to replicate music albums. Both acrylics and aluminum are inputs in the production of the petrochemical industry. CDs, in their turn, are inputs for the phonographic industry. An artist's music album is the resulting production of this process, but that can also be an input from other cultural segments, such as cinema, performing arts, etc. Another example would be production of live-action series in television networks. Inputs such as costume design, sound equipment for editing and mixing, scenography, transport, among others, mobilize other non-artistic economic segments and the final product is commercialized, publicized and even exported to other countries.

\subsection{Cultural Policies and the Programa Cultura do Trabalhador}

Although classical political economists already discussed the peculiarities of artistic cultural activities, including public funding [11] [12], Baumol and Bowen

[13] is the work regarded as the pioneer in studies of cultural economics and public funding. In their book, Performing arts: the economic dilemma, the authors' conclusion support that government should provide funding for the performing arts, such as theatre and dance. The main reason is that, as these activities are labor-intensive, high production costs would not decrease with technological development; in other words, there would be no great enough productivity gains. A theater play, for example, would be limited by actors' fatigue and the lack of profitability in short-season performances, given scenography and advertising costs.

Cwi [14] and Frey [15] summarize more reasons why the government should support the arts. The first one regards benefits generated to indirectly involved ${ }^{3}$ Hirschman also discusses consumption linkage and tax linkage, but these will not be dealt with in this study. 
sectors through linkage effects. Another reason is the implicit demand of the sector, which is linked to the fact that some people recognize the importance of artistic and cultural products, even if they do not actually spend money on them; they simply appreciate them. Singh [16] explained that R\&D promoted creativity and therefore encourages growth.

Public policies can focus either on producers or consumers. There is no consensus on which type of policy is the ideal, thus it depends on which objectives the government wants to achieve with a policy [17]. Generally, policies focused on producers seek to provide better financing to the artists, associations or businesses, which could diversify the goods and services offered. In Brazil, the Ministry of Culture, ever since its creation in 1985, has used such mechanisms, through fiscal incentives to companies. The main source of financing to national producers comes first from the Rouanet Law [18]. Now the adoption of policies focused on consumers is usually associated with the formation of habits or to study the nature of cultural goods and services. Estimations of demand functions and price and income elasticities for the cultural sector frequently point that its demand income-elasticity, when treated homogeneously, is higher than from other goods, which suggests that these goods and services should be characterized as luxury goods [4].

An alternative to increase access to cultural goods and services would be the voucher system. In the voucher distribution system ${ }^{4}$, a certain group of consumers receive an increase in their income, by the form of a ticket or card, to obtain cultural products. By increasing people's actual income, the voucher will stimulate consumption and enable the consumer to make more effective choices. Supporters of the system believe vouchers can help developing tastes and habits [20], which would represent changes in consumption, not only in the short term but also in the long term.

Concerning the issue of vouchers given directly to consumers, the work of Peacock [21] is seminal, proposing this system for low-income individuals. West [22] makes the same argument, arguing that subsidies should be provided to individuals with lower income and education, the ones that need them most. According to Van der Ploeg [23], provision of vouchers, especially to young people, can be an efficient means of promoting demand for more sophisticated artistic products, or "high culture", among individuals who do not normally consume such goods and services. There have been international experiments with vouchers in Ontario and Minneapolis, as well as in European countries and important cultural players such Broadway [24].

It can be observed that most of these programs aim to use resources more efficiently, focusing on individuals that are more likely to consume cultural goods

${ }^{4}$ The voucher is a system that permeates culture when it comes to the issue of public policies which are not restricted to encouraging consumption, although this is the aspect that matters in the proposed discussion. A detailed analysis about the voucher concept and its variations in the scope of public policies can be seen in [19]. 
and who can cultivate the habit of demanding goods and services from the cultural industry. In Brazil, the most recent example of this kind of policy is the Vale-Cultura, an initiative from the Programa Cultura do Trabalhador, which, unlike most of the cases presented, focuses on inclusion of individuals who cannot afford these items.

The Programa Cultura do Trabalhador was created by the federal government [25] to provide the population access to products of the cultural industry and to stimulate the consumption of cultural products. This program is carried out through the Vale-Cultura, a personal, nontransferable voucher, valid throughout the country, which can be used to buy the products ${ }^{5}$. The objective of the government is not only to democratize and qualify the access to cultural goods and services, but also to foment consumption habits, so that using vouchers can be an adequate strategy. This program follows the increase of expenditure volume in the cultural sector, something that has been verified through the years, specially between 2007 and 2010, according to IBGE.

The voucher is provided as a prepaid magnetic card, issued by a card manufacturer hired by the company that wants to join the program. To use the card, the receiving store must be authorized by the card manufacturer. Employers' participation in the program is therefore optional, and they must register with the Ministry of Culture to participate in it. Companies that opt to participate are exempt from social and labor charges on the amount of the benefit from the federal government. In addition, the government will grant a deduction of up to $1 \%$ of the actual profit from the income tax of these companies.

The monthly value stipulated is $\mathrm{R} \$ 50.00$, and part of this amount may be deducted from the employee's salary ${ }^{6}$. This represents roughly $0.05 \%$ of minimum wage, in 2017 values. The benefit can be accumulated indefinitely or used in conjunction with other forms of payment at the time of purchase of the products. The program is provided for workers whose income is up to five minimum wages (monthly) and is regularly employed. However, the employer has the option of offering the benefit for individuals with higher wages, as long as the totality of employees focused by the government be attended [25].

The Vale-Cultura started being offered in January 2014. By June 2016, there were 398,088 beneficiaries. The cumulative amount used in purchases of cultural products was $\mathrm{R} \$ 307488698.37$ in 30 months. Of this amount, $22.7 \%$ was spent ${ }^{5}$ The list of these products is determined by the Ministry of Culture and may be changed over time. Currently, the genres offered for the use of the voucher are: crafts and sculpture; movie tickets, art exhibitions, festivals, circuses, theatre, music and dance; visual arts equipment and musical instruments; audiovisual courses, arts, circuses, dance, photography, music, theater and literature; DVDs and CDs; newspapers, books, sheet music and magazines; photography, paintings and engravings. ${ }^{6}$ To the worker earning up to five minimum wages, the discount in payment is option by the employer and, at best, $10 \%$ of the benefit, in other words, $\mathrm{R} \$ 5.00$, according to article 15 of the decree $\mathrm{n}^{\circ} 8,084 / 2013$. Who gains up to one minimum wage pays $\mathrm{R} \$ 1.00$ (one real). Over one and up to two minimum wages, the discount is $\mathrm{R} \$ 2.00$ (two reais). Over two and up to three, RS3.00 (three reais). Over three and up to four, $\mathrm{R} \$ 4.00$ (four reais). Over four and up to five, $\mathrm{R} \$ 5.00$ (five reais). For the workers who gain above this value, the discount is obligatory and varies between $20 \%$ and $90 \%$ of the benefit value, in other words, it can reach $\mathrm{R} \$ 45$ (forty-five reais) [25]. 
on cinema and $64.6 \%$ in books and magazines $[26]^{7}$. The number of workers receiving the Vale-Cultura is still below the government's expectations, which intended to benefit 16 million workers by 2020 . This goal has changed to 3 million workers by 2020 in February 2016.

The Vale-Cultura, as a direct income transfer program based upon the use of specific goods and services hypothetically causes a positive income shock on its recipients, as well as an impact on economic activity. In this study, we propose an ex-ante evaluation methodology of the effects of the program from a general equilibrium approach. The general equilibrium framework allows analysis of changes in household spending in the face of an income shock in which the consumption vector is considered.

\section{Methodology}

\subsection{The BRIDGE Model}

Computable general equilibrium (CGE) models are important instruments to build consistent simulations that consider inter-sectoral effects. Compared to traditional models, such as input-output, one advantage of CGE models is that they allow adopting hypotheses involving endogenously determined reallocation of resources and flexible prices, as in this study.

Economic literature frequently uses CGE models in simulations of the impact of public policies. In Brazil, for example, we have studies on impact of Minha Casa Minha Vida (a federal housing funding program for low income families) [27] and Farmácia Popular (a prescription drug subsidy program) [28]. In the cultural sector, however, studies are rare, not just in Brazil but around the world. This is caused by their complexity and difficulties with data collection and availability. The model is effectively used in a report on the impacts of government funding on the cultural sector in Victoria, Australia's artistic capital. The study used the TERM model (The Enormous Regional Model) [29], which analyzes how changes in the cultural sector flow to other sectors in the long term. The results showed that, for every $\mathrm{A} \$ 1.00$ spent annually by the government on arts and culture, A $\$ 1.90$ net was generated for the economy of Victoria [30].

The CGE model used here is the Brazilian Recursive Dynamic General Equilibrium Model (BRIDGE), developed from the theoretical structure of ORANI [31] and MONASH [32], including elements of recursive dynamics, that produce sequences of solutions connected by dynamic relationships such as labor market adjustments and physical capital accumulation. Therefore, it is a Johansen-type model whose mathematical structure is formed by a set of linearized equations, and the solutions are given by the growth rates, i.e. elasticities.

The theoretical structure of the BRIDGE model ${ }^{8}$ derives from a of the MONASH

${ }^{7}$ In December 2014, the number of beneficiaries was 338,312, and the annual aggregate amount of $\mathrm{R} \$ 69558750.26$. Already in December 2015, the figures were, respectively, 385,448 and R\$158778667.45 [26].

${ }^{8}$ This paragraph is based on Domingues et al. [33]. 
model, a CGE model of the Johansen type represented by a set of linearized equations and that follows some of the standard specification of CGE models ${ }^{9}$. In all markets, the model assumes perfect competition, with the productive sectors acting to minimize production costs for given constant returns to scale technology. The combination of intermediate inputs and primary factors is established by fixed factors, i.e. the Leontief-type model. The composition of domestic and imported inputs follows a constant elasticity of substitution (CES) function. Although all sectors present the same theoretical specification, the substitution effect via prices differs according to the composition between imported and domestic raw materials. The hypothesis of a small country in international trade is adopted, wherein sectoral exports respond to demand curves negatively associated with the domestic costs of production and are positively affected by the exogenous expansion of international income. Investment and capital stock follow mechanisms of offset and inter-sectoral accumulation associated with depreciation and return rates. The household demand follows a Stone-Geary nonhomothetic utility function. Government consumption is endogenous and the labor market presents an intertemporal adjustment feature, involving variables such as current employment, real wage and trend employment. Appendix presents the equations of the model.

The calibration of the BRIDGE model is made based on the Brazilian input-output matrix (IOM) for the year 2005, the latest version released by IBGE. The IOM is constructed from the Brazilian National Accounts System and corresponds to a matrix of direct technical coefficients indicating how much a specific economic activity needs to consume from others in order to produce an additional currency unit. It has a structure comprising of 55 sectors, 110 products, five components of final demand (household consumption, government consumption, investment, exports and inventories), two primary factor (capital and labor), two margin sectors (trade and transport), imports by product for each of the 55 sectors and five components of final demand, an aggregate of indirect taxes and an aggregate of taxes on production [37]. Additionally, the parameters used in the model were taken from previous work [34] and the usual references in the literature, for example the Armington elasticities [38] and Frisch parameter [39].

The Family Budget Survey (FBS), a sample survey conducted by the Brazilian Institute of Geography and Statistics (IBGE) for the period 2008/2009, was used to construct the vectors of household consumption and the income shock value resulting from the implementation of the Vale-Cultura.

${ }^{9}$ More details in [28] and [33]. This model has been developed at the Center for Development and Regional Planning (CEDEPLAR), Federal University of Minas Gerais (UFMG). It was first used by Domingues et al. [34] to analyze the effects of the economic slowdown caused by the economic crisis of 2009 in the Brazilian scenario. The model was later used by Souza and Domingues [35] in a study on the economic impacts of changes in the domestic Brazilian services market between 2006 and 2011. Domingues et al. [28], in simulations on the effect of the ProgramaFarmácia Popular in the reallocation of household spending; Cardoso et al. [36], in evaluating the impacts of payroll relief according to policies adopted by the federal Government. 
Finally, it is worth mentioning that the absence of any specific satellite data for cultural goods and services prevents a more careful analysis of this sector. This does not allow a greater degree of detail in the CGE model, as well as because it establishes a dependency of the studied period of the FBS data that, in this case, are somewhat delayed in relation to the Programa Cultura do Trabalhador. It is assumed, therefore, that the structure of expenditures does not vary widely between periods in the FBS sampling and the implantation of the Vale-Cultura, which is a plausible hypothesis.

\subsection{Simulation Procedures}

This study organizes information according to the household framework ${ }^{10}$. This choice was made because FBS expenditure values cannot be computed individually in their entirety, as would be desirable. Spending in some of the goods and services of the sample is based on individual information provided through a specific questionnaire. However, not all items have this level of stratification, making it impossible to break down spending to the individual level. In addition, CGE methods use the concept of representative families, not of persons. Based on this assumption, the cut of the households is based on the figure of the family head as the representation of each family, so that individuals who are not heads of family are removed from the sample. Such households are divided into two groups: those families that are eligible for the program, and those families that are not eligible for the program. Eligible families are those in which the respective heads receive up to five minimum wages and are regularly employed. Ineligible households are those in which the heads earn more than five minimum wages and all those who are not registered under the Consolidated Labor Laws (CLT), regardless of the value of the salary.

The standard monthly minimum wage considered is $\mathrm{R} \$ 415.00$ (four hundred and fifty reais), based on data from 15, January 2009. This study uses a FBS sample of 7533 households, in which 1771 comprise the eligible group and 5762 the ineligible group. Using the expansion factor of the sample, the total is $3,916,420$ eligible households and 13,787,427 ineligible households.

Each FBS consumption item was associated with one of the 110 IOM products, which seven out of these are related to goods and services that may be purchased using the Vale-Cultura: market education; newspapers, magazines, disks and other recorded products; services oriented toward families; furniture and products from different industries; wood products, furniture made-to-order; manufacture of other textile products; and, other non-metallic, mineral products. In order to make a more practical analysis, the other FBS consumption ${ }^{10}$ Our analysis focus in nine metropolitan regions: Belém, Fortaleza, Recife, Salvador, Belo Horizonte, Rio de Janeiro, São Paulo, Curitiba and Porto Alegre. This option is based on the hypothesis widely discussed in the literature on the concentration of the consumption of cultural products in large urban centers, with a tendency of the agglomeration process of the artistic-cultural activities according to the local economic activity. As the simulations have as hypothesis the almost complete adherence on the part of the eligible individuals, to consider only this part of the Brazilian population is an option more compatible with the exercise proposed here. 
items have been reaggregated according to the similarity of their characteristics and their association with the respective IOM products, comprising 35 products $^{11}$. The consumption vector of eligible and ineligible households was constructed from their spending data.

The number of individuals eligible for the program is necessary to calculate the income shock value of the program. The FBS is also the starting point to find such values, with the selection of heads of households as the FBS variable that is closest to this concept.

Using only the FBS to obtain the number of individuals eligible for the program is problematic, since it is only possible to construct the spending vector by considering the of the head of household figure as the beneficiary. A Vale-Cultura voucher is individual and, thus, allows more than one member of the household to receive the benefit, provided they follow the rules laid down by the government. There is, therefore, a limitation in the identification of the number of eligible individuals and, thus, in the possible income shock value. Data from the National Research by Household Sample (PNAD) was used as a way to alleviate this data limitation, since it offers the possibility of working with a more stratified sample. The idea is to create an index from the PNAD, that represents the number of individuals eligible for the program in each household, and thus to associate them with the FBS.

To identify the potential net value of transfers from Vale-Cultura, the number of eligible individuals is multiplied by the net value of the monthly benefit, specific for each salary level, and by the number of months of the year. The net amount of the monthly benefit varies between $\mathrm{R} \$ 45.00$ and $\mathrm{R} \$ 50.00$, considering that part of the amount can be deducted from the payroll of the individual by the company, as already discussed.

The total transfer of the Vale-Cultura calculated for the eligible families is $\mathrm{R} \$ 4,664,000,000$. However, as the values used in the simulations come from the IOM, the amount needs to be deflated for the year 2005. Using the Consumer Price Index (IPCA) at 1.14, the total value of transfers is calculated as $\mathrm{R} \$ 4,088,000,000$. It is worth mentioning that there are still individuals who could receive the benefit, but are not considered in this study.

We assume the following hypotheses for the simulation: 1) the first one relates to the number of individuals receiving the benefit. Participation was still weak by the time this study was being developed, which is justified by the fact that Vale-Cultura was relatively recent and depending on the companies to offer it to their employees. Thus, with the goal of trying to get the maximum effect of the

${ }^{11}$ The 35 products are: farming and cattle raising; mining; food, beverages and tobacco; textiles, clothing and footwear; other textiles; leather; wood; cellulose; paper; newspapers, magazines and disks; chemicals and fuel; pharmaceutical products, perfumes, pesticides and rubber products; paints; various chemicals; plastic; cement and steel; other non-metallic minerals; metal products; machinery, automobiles and trucks; home appliances; office and informatics; electronics; furniture; Industrial Services of Public Utilities; construction; commerce; transportation; services; information services; real estate services; repair and maintenance services; lodging services; market education; family services; public administration. 
program, the hypothesis of full participation by individuals from eligible households, totaling 8,346,947 people, is adopted herein. This value was found using FBS data and applying the index constructed from the PNAD. Although it is a strong hypothesis, it still does not include all possible beneficiaries. Ineligible households, for example, may contain eligible people. Table 1 presents all the possible scenarios. And 2) the monetary value is fully spent by the households, even though the voucher does not necessarily need to be used and may be accumulated indefinitely.

The impact of the Vale-Cultura is calculated as the ratio between the net value of the benefit and the total value of the consumption expenditure of a certain group of individuals. All these values were calculated in $\mathrm{R} \$$ in 2005 , the base period of the IOM. According to our simulations, the impact of the shock equals $3.26 \%$ in aggregate expenditure, in actual private consumption of eligible households (deflated value for the base year of the model, 2005). The transfer value would be $\mathrm{R} \$ 4088$ million in 2005 values, corresponding to $0.118 \%$ of GDP and $0.288 \%$ of household consumption.

With this shock, the expected result of the model is a positive reallocation of the consumption vector, but only for the seven products related to cultural goods and services that can be purchased using the Vale-Cultura, considering that this resource cannot be spent on products other than those determined by the program. That is, there is an offset to the right of the demand curve for those products to families who receive the Vale-Cultura benefit.

In all seven impacted sectors, however, there are goods and services that cannot be purchased using Vale-Cultura, thus the group of items that receive the shock in the simulations is overrated. This percentage can be seen in Table 2. This is a problem that still cannot be resolved with the available data. In turn, the effect generated in the more specific cultural product cannot be calculated directly, as the result of simulations performed here considers the application of the shock to the set of products.

The simulations consider that the extra income to be passed on to the families would come entirely from the government, because even if the value is passed on by the companies they receive compensation in the form of tax relief. The government, in turn, hypothetically does not pay this amount in its consumption of goods and does not change the tax burden to finance the program. This means that the implementation of the program would increase the public deficit marginally, and that it would have no real effect on the economy. Alternatively, a simulation hypothesis could be adopted in which the transfer would be compensated by either cutting government consumption or raising taxes. However, there is no information about the empirical validity of this hypothesis.

The model closure, which indicates the set of variables defined as exogenous and endogenous, is long-term. In a closure like this, the capital stock is variable and adjusts itself to maintain a fixed rate of return. Employment is exogenous and real wages are endogenous. The number of households and their preferences are exogenous. Investment is endogenous by sector and in the aggregate. 
Table 1. Information on household eligibility in simulation exercises.

\begin{tabular}{l}
\hline \multicolumn{1}{c}{ Eligible and ineligible specification } \\
\hline $\begin{array}{l}\text { Eligible: a head of household who earns up to five minimum wages and is regularly employed. } \\
\text { Ineligible: a head of household who earns more than five minimum wages and/or is employed in } \\
\text { the informal labor market. }\end{array}$ \\
\hline \multicolumn{1}{c}{ Problems of the specification chosen } \\
Households whose head earns up to five minimum wages: it can include more than one \\
beneficiary. Solution employed: use PNAD-FBS index in the eligible group. \\
Households whose head earns more than five minimum wages: the head of household is \\
ineligible, but other eligible individuals can reside in the household. These were then \\
disregarded. \\
Individuals who could receive the benefit in large group settings, but are not \\
considered eligible (part of the ineligible group)
\end{tabular}

a. Elaborated by the authors.

Table 2. Spending on items from Vale-Cultura in every IOM product according to FBS information 2008-2009 (\%).

\begin{tabular}{ccccc}
\hline \multirow{2}{*}{ Products } & \multicolumn{2}{c}{ Eligible families } & \multicolumn{2}{c}{ Ineligible families } \\
\cline { 2 - 5 } & $\begin{array}{c}\text { Items on the list of } \\
\text { Vale-Cultura }\end{array}$ & Other items & $\begin{array}{c}\text { Items on the list of } \\
\text { Vale-Cultura }\end{array}$ & Other items \\
\hline $\begin{array}{c}\text { Other textile } \\
\text { Wood }\end{array}$ & 0.05 & 99.95 & 0.05 & 99.95 \\
$\begin{array}{c}\text { Newspapers, magazines } \\
\text { and disks }\end{array}$ & 70.11 & 34.71 & 91.79 & 8.21 \\
$\begin{array}{c}\text { Other non-metalic } \\
\text { minerals }\end{array}$ & 0.81 & 29.89 & 83.49 & 16.51 \\
Furniture & 1.01 & 99.19 & 3.26 & 96.74 \\
Market education & 1.17 & 98.83 & 3.79 & 96.21 \\
Family services & 7.01 & 92.99 & 1.17 & 98.83 \\
\hline
\end{tabular}

b. Elaboration based on information from FBS, 2008-2009.

Income shocks cause a reallocation of the consumption vector that, in turn, impacts the demand for both domestic and imported products. In the case of domestic supply, despite the possibility of reallocation of the work factor among the sectors, this reallocation is done imperfectly, which generates an impact on production costs and relative prices. Thus, price and activity effects create changes in the levels of export, import and investment. Real consumption adjusts itself endogenously, responding to the income shock. In the case of house- 
holds that receive the extra income from the Vale-Cultura, only the consumption of the seven products of the program is adjusted; if the family is not part of the group that receives the income shock, all products can be changed. Finally, real consumption of goods and services of the government is exogenous.

The results concerning the impact adopting the Vale-Cultura, presented in comparative statistics, always refer to the deviation caused by the shock relative to a situation in which this shock does not occur. The GEMPACK software was used to make the simulations ${ }^{12}$.

\section{Results}

Table 3 presents the impact on household consumption of eligible and ineligible households. The demand for the seven products present in the Vale-Cultura list would change around $60 \%$ for the eligible families. The demand by these families for other products would not change at first, since individuals will not be able to spend the extra income on other items, except those on the program list. For this reason, the value of the impact on consumption in the other products for the eligible families will be zero. Due to changes in relative prices, the consumption of other goods would change marginally, as shown in the column "Total".

The shock does not affect the families of ineligible households. They would notice a change in the consumption of all products, including a negative variation in most cultural products. This is due to the increase in price of the items of these products, forced by the increased demand of the benefitted group. In the aggregate, there is a reallocation of the consumption vector of these individuals for the other products as they become relatively cheaper. Consequently, Vale-Cultura redistributes the consumption of cultural goods and services from ineligible to eligible individuals. Among those products that showed a negative variation and do not belong to the cultural sector, the affected ones are maintenance and repair services $(-0.011 \%)$; farming and cattle raising $(-0.012 \%)$ and services $(-0.013 \%)$.

Concerning the impacts on welfare, there are two ways to measure them, in monetary terms: compensating variation (CV) and equivalent variation (EV). They are especially useful to measure effects of thein relative prices and in the basket of goods consumed by the households. Compensating variation indicates monetary indexation that compensates any change in the well-being of the individual caused by change in the parameters of the budgetary constraint. In other words, the $\mathrm{CV}$ is the amount that leaves the individual in their original indifference curve; i.e. in the same initial basket of goods for a given price variation. Equivalent variation represents the variation in income that is equal to a variation of prices, in terms of variation of utility, which means a new basket of goods. Therefore, the EV represents the amount of currency that should be

${ }^{12}$ The simulations were done with GEMPACK version 11. More details about use of CGE models in this software may be found in [40]. For more details about the software itself, visit http://www.copsmodels.com/gempack.htm. 
Table 3. Impact of Vale-Cultura on household consumption (\% chg.).

\begin{tabular}{|c|c|c|c|}
\hline Products & $\begin{array}{l}\text { Eligible } \\
\text { families }\end{array}$ & $\begin{array}{c}\text { Ineligible } \\
\text { families }\end{array}$ & $\begin{array}{c}\text { Aggregate } \\
\text { variation }\end{array}$ \\
\hline Farming and cattle raising & 0 & -0.012 & -0.01 \\
\hline Mining & 0 & 0.012 & 0.01 \\
\hline Food, beverages and tobacco & 0 & -0.006 & -0.005 \\
\hline Textile, clothing and footwear & 0 & -0.01 & -0.009 \\
\hline Other textiles & 60.505 & 0.003 & 4.631 \\
\hline Leather & 0 & 0.017 & 0.016 \\
\hline Wood & 60.895 & -0.009 & 0.846 \\
\hline Cellulose & 0 & 0.019 & 0.01 \\
\hline Paper & 0 & 0.004 & 0.003 \\
\hline Newspapers, magazines and disks & 59.38 & 0.001 & 3.217 \\
\hline Chemicals and fuel & 0 & 0.028 & 0.024 \\
\hline Pharmaceuticals, perfumes, pesticides and rubber products & 0 & 0.046 & 0.04 \\
\hline Paint & 0 & 0.024 & 0.022 \\
\hline Various chemicals & 0 & 0.088 & 0.052 \\
\hline Plastic & 0 & 0.057 & 0.053 \\
\hline Cement and steel & 0 & 0.021 & 0.018 \\
\hline Other non-metallic minerals & 59.723 & 0.025 & 3.562 \\
\hline Metal products & 0 & 0.032 & 0.028 \\
\hline Machinery, automobiles and trucks & 0 & 0.029 & 0.028 \\
\hline Home appliances & 0 & 0.011 & 0.009 \\
\hline Office and informatics & 0 & 0.064 & 0.059 \\
\hline Electronics & 0 & 0.051 & 0.043 \\
\hline Furniture & 60.914 & 0.003 & 5.546 \\
\hline Industrial services of public utilities & 0 & 0.012 & 0.011 \\
\hline Construction & 0 & 0.025 & 0.013 \\
\hline Commerce & 0 & 0.022 & 0.011 \\
\hline Transportation & 0 & 0.013 & 0.011 \\
\hline Services & 0 & -0.013 & -0.013 \\
\hline Information services & 0 & 0 & 0 \\
\hline Real estate services & 0 & 0.016 & 0.015 \\
\hline Maintenance and repair services & 0 & -0.011 & -0.01 \\
\hline Lodging services & 0 & 0.014 & 0.012 \\
\hline Market education & 60.718 & -0.056 & 1611 \\
\hline Services for the family & 60.692 & -0.04 & 2.721 \\
\hline Public administration & 0 & 0.017 & 0.008 \\
\hline
\end{tabular}

c. Elaborated based on simulation results. 
removed from the consumer to leave them as well off as after price variation [41].

Table 4 shows that families from eligible households would have an increase in their welfare. The compensating variation (CV) refers to the amount of additional money a household would need to reach her initial utility after a change in prices $^{13}$. In Table 4, we have reported the negative value of CV in order to highlight that the benefit is positive to eligible families and negative to ineligible families. There is a negative response in the welfare of ineligible families due to the upward price variation in the economy. Other figures in Table 4 show that the eligible families would increase their participation in the economy. The negative value of the Consumption/GDP ratio reflects the change in relative prices for ineligible families.

A sectoral analysis is also important for understanding the interdependence and linkage effects. Table 5 presents the accumulated variations in production levels; that is, variations in the level of activity or Added Value. As expected, the products that would receive the shock from Vale-Cultura would have a positive variation, showing greater reallocation of productive factors around these products and, consequently, proportionately larger production.

Table 5 shows the variation in production prices of goods. The numbers are consistent with the data analyzed so far, such as increase in price levels in sectors that received the income shock. These values help in the understanding of the sectoral results and the increase in the final price to the consumer.

Table 6 shows that the adoption of the program would increase indirect tax collection, such as ICMS and IPI, as well as taxes on production, such as PIS, COFINS and IRPJ significantly, which would offset much of the expense related to the implementation of the program. The ratio of total tax revenues generated by the value of the transfers is 0.8718 . That is, for every $\mathrm{R} \$ 1.00$ spent on the program, $\mathrm{R} \$ 0.87$ is returned to the economy in the form of taxes ${ }^{14}$. Therefore, the hypothesis of a small impact of the program on public debt, and the lack of necessity to adjust government consumption or taxes to finance the program appears reasonable. However, it points that the program's budget would increase if the number of people participating in the program increased as well.

Finally, in terms of macroeconomic aggregates, Table 7 shows there would be a $0.07 \%$ change in the actual GDP; i.e. it would be $0.07 \%$ higher in the scenario with Vale-Cultura than in a scenario without it. GDP growth would be driven by

\footnotetext{
${ }^{13}$ The compensating variation is the change in utility measured in final price units. It is defined as the cost of moving to the final level of utility at the final prices. In our model, the linear expenditure system (LES) derived from the Stone-Geary utility function implies that the CV would be related to the "luxury" consumption change minus the initial utility evaluated at final prices. As the income transfers impact directly the "luxury" consumption, the eligible families experience welfare gains. See [42] and [43].

${ }^{14}$ The result is proportional to what we estimate in relation to tax returns of income transferences, given the linear structure of the model. That is, it will always generate $\mathrm{R} \$ 0.87$ per monetary unit transferred from income. Thus, if the program costs $\mathrm{R} \$ 10$ billion of transfer, it generates $\mathrm{R} \$ 8.7$ billion in taxes.
} 
Table 4. Impact of Vale-Cultura on welfare of families (in R\$ from 2005).

\begin{tabular}{ccc}
\hline Measurement & Eligible families & Ineligible families \\
\hline (negative of) Compensating Variation (R \$ million) & 3962.88 & -23.78 \\
Consumption/GDP (\% chg.) & 3.1 & -0.15 \\
Consumer price index (\% chg.) & 0.54 & 0.55 \\
Real consumption (\% chg.) & 3.26 & 0 \\
\hline
\end{tabular}

d. Elaborated based on simulations results.

Table 5. Impact of Vale-Cultura on the Added Value and the general price of production of goods produced locally (\% chg.).

\begin{tabular}{|c|c|c|}
\hline Products & Value added & Price \\
\hline Farming and cattle raising & -0.18 & 0.59 \\
\hline Mining & -0.23 & 0.51 \\
\hline Food, beverages and tobacco & -0.14 & 0.58 \\
\hline Textile, clothing and footwear & 0.07 & 0.58 \\
\hline Other textiles & 1.83 & 0.54 \\
\hline Leather & -0.13 & 0.59 \\
\hline Wood & 0.28 & 0.59 \\
\hline Cellulose & -0.5 & 0.53 \\
\hline Paper & 0.14 & 0.53 \\
\hline Newspapers, magazines and disks & 0.93 & 0.55 \\
\hline Chemicals and fuel & -0.08 & 0.43 \\
\hline Pharmaceuticals, perfumes, pesticides and rubber products & -0.09 & 0.5 \\
\hline Paint & 0.09 & 0.46 \\
\hline Various chemicals & -0.07 & 0.46 \\
\hline Plastic & -0.02 & 0.49 \\
\hline Cement and steel & -0.21 & 0.47 \\
\hline Other non-metallic minerals & 0.03 & 0.56 \\
\hline Metal products & -0.09 & 0.53 \\
\hline Machinery, automobiles and trucks & -0.24 & 0.49 \\
\hline Home appliances & -0.05 & 0.52 \\
\hline Office and informatics & 0.05 & 0.33 \\
\hline Electronics & -0.04 & 0.41 \\
\hline Furniture & 2.98 & 0.54 \\
\hline Industrial services of public utilities & 0.02 & 0.52 \\
\hline Construction & 0.11 & 0.55 \\
\hline Commerce & 0.16 & 0.61 \\
\hline Transportation & -0.18 & 0.57 \\
\hline Services & -0.02 & 0.58 \\
\hline Information services & -0.01 & 0.55 \\
\hline Real estate services & -0.08 & 0.53 \\
\hline Maintenance and repair services & 0.01 & 0.57 \\
\hline Lodging services & -0.17 & 0.6 \\
\hline Market education & 1.54 & 0.69 \\
\hline Services for the family & 2.32 & 0.66 \\
\hline Public administration & 0 & 0.7 \\
\hline
\end{tabular}

e. Elaborated based on simulation results. 
Table 6. Impact of Vale-Cultura on tax revenues.

\begin{tabular}{cc}
\hline Tax & Variation \\
\hline Indirect taxes (R\$ million) & 3397 \\
Production taxes (R \$ million) & 167 \\
Program transfer (R \$ million) & 4088 \\
Tax revenues generated/Transfer (in \%) & 0.8718 \\
\hline
\end{tabular}

f. Elaborated based on simulation results.

Table 7. Impact of Vale-Cultura on the macroeconomic variables (\% chg.).

\begin{tabular}{cc}
\hline Macroeconomic variables & $\%$ chg. \\
Real GDP & 0.07 \\
Family consumption & 0.31 \\
Investment & 0.12 \\
Exports & -0.61 \\
Imports & 0.37 \\
Use of Work factor & 0 \\
Use of the Capital factor & 0.12 \\
Shock \% of the GDP & 0.118 \\
Variation \% of the GDP/Shock \% of the GDP & 0.593 \\
Tax revenues generated/Transfer (in \%) & 0.872 \\
\hline
\end{tabular}

g. Elaborated based on simulation results.

the increased use of capital on the factor side and household consumption on the absorption side. The investment, which depends on the return of capital and on the rate of return of capital, has a positive variation.

Considering that cultural goods and services still have strong limitations in the shopping basket of part of the population, the result of Vale-Cultura on GDP calls the attention to relevant changes. One indicator that shows the relevant effect of the shock is the ratio between the percentage change of the GDP as a function of the shock and the shock percentage on the GDP, indicating the generator effect of the shock. In the present study, the multiplier effect was of 0.593 , which means that for every $\mathrm{R} \$ 1.00$ invested in the program, the return generated for the economy would be $\mathrm{R} \$ 0.59$. In comparative terms, the study carried out in the Australian city of Victoria, which used a TERM model having a long-term closing, resulted in a 1.9 multiplier effect [30].

A possible marginal deficit may be seen in the balance of trade, regarding both the positive impact on imports that responds to the increase in relative prices (ratio between domestic and imported prices) and would have a positive variation of $0.12 \%$, as well as the negative impact on exports that responds negatively to the increase in domestic prices. Exports would have a negative variation of 
$0.61 \%$. Such a result can be understood as a way of absorbing the expansion of consumption by individuals who received the benefit. This indicates that this public policy, prioritizing domestic consumption, eventually deteriorates foreign trade.

The higher prices and internal costs (Table 4) associated with the growth of the GDP suggest that the adoption of Vale-Cultura promotes both an activity-effect and a price-effect. The latter, however, although negatively affecting the commercial balance, is not sufficient to offset the positive effect of the activity-effect.

The key parameters in the simulations refer to the allocation of household consumption between "luxury" and "subsistence" expenditure (Frisch parameter). Sensitivity tests showed that there was no significant change in results when we change this parameter.

\section{Final Considerations}

This present work aims to study the economic effects of the implementation of the Programa Cultura do Trabalhador, using a computable general equilibrium model.

The results indicate a growth in the real GDP of around $0.07 \%$, driven mainly by the increase in household consumption on the absorption side. The multiplier effect was 0.59 , which indicates that this GDP growth was significant. As for consumption, the implementation of Vale-Cultura would create a positive variation in demand, that spills over to the sectors of the economy that supplies goods eligible by the voucher. As for the ineligible group, it did not have effects, although there are differences due to price variation. In this situation, cultural services and goods become relatively more expensive, which implies a reallocation of the consumption vector towards other goods.

Families from eligible households would have increased welfare. The collection of indirect taxes and taxes on products is also positively affected due to various effects in the economy, like the price variation, which partly would make up for the transfer from government to the companies via tax exemption. In terms of sector analysis, positive growth in the level of activity of the cultural sectors and negative in some others is seen, showing a reallocation of productive factors and an increase in the cost of production. Among the sectors that are not affected by the shock, paper, textile, and paints stand out. They are indirectly connected with some of the cultural products.

Such results are important and do not only justify the program's adoption by the federal government, but also suggest that its expansion is interesting from an economic point of view.

Finally, the pioneering character of this study for the Brazilian case stands out. Such a line of research may create important data to understand the cultural sector in Brazilian economy; thus it is an area of research that should be further explored and discussed. 


\section{Conflicts of Interest}

The authors declare no conflicts of interest regarding the publication of this paper.

\section{References}

[1] Diniz, S. and Machado, A. (2011) Analysis of the Consumption of Artistic-Cultural Goods and Services in Brazil. Journal of Cultural Economics, 35, 1-18. https://doi.org/10.1007/s10824-010-9129-8

[2] Paglioto, B. and Machado, A.F. (2012) Perfil dos frequentadores de atividades culturais: O caso nas metrópoles brasileiras. Estudos Econômicos, São Paulo, 701-730. https://doi.org/10.1590/S0101-41612012000400003

[3] Silva, F.B., Araújo, H.E. and Souza, A.L. (2007) O consumo cultural das famílias brasileiras. In: Silveira, F.G., et al., Eds., Gasto e consumo das famílias brasileiras contemporâneas, IPEA, Brasília, 105-142.

[4] Throsby, D. (2011) Economics and Culture. Cambridge University, Cambridge.

[5] Bille, T. and Schulze, G.G. (2006) Culture in Urban and Regional Development. In: Ginsburgh, V.A. and Throsby, D., Eds., Handbook of the Economics of Art and Culture, 2nd Edition, North-Holland Elsevier, Oxford, 1051-1099. https://doi.org/10.1016/S1574-0676(06)01030-1

[6] Santagata, W. (2006) Cultural Districts and Their Role in Developed and Developing Countries. In: Ginsburgh, V.A. and Throsby, D., Eds., Handbook of the Economics of Art and Culture, 2nd Edition, North-Holland Elsevier, Oxford, 1101-1122. https://doi.org/10.1016/S1574-0676(06)01031-3

[7] Singh, A.P. (2016) R\&D Spillovers \& Productivity Growth: Evidence from Indian Manufacturing. Indian Journal of Industrial Relations, 51, 563-579.

[8] Marshall, A. (1982:1890) Princípios de economia. Abril Cultural, São Paulo.

[9] Markusen, A.A. (2007) Consumption Base Theory of Development: An Application to the Rural Cultural Economy. Agricultural and Resource Economics Review, 36, 15. https://doi.org/10.1017/S1068280500009412

[10] Hirschman, A.O. (1961) Estratégia do desenvolvimento econômico. Fundo de Cultura, Rio de Janeiro.

[11] Goodwin, C. (2006) Art and Culture in the History of Economic Thought. In: Ginsburgh, V.A. and Throsby, D., Eds., Handbook of the Economics of Art and Culture, 2nd Edition, North-Holland Elsevier, Oxford, 26-69. https://doi.org/10.1016/S1574-0676(06)01002-7

[12] Martos, L.A.P. and Quintero, L.F.A. (2011) Debe el Estado financiar las artes y la cultu-ra? Revisión de literature. Economia e Sociedade, Campinas, 195-228. https://doi.org/10.1590/S0104-06182011000100008

[13] Baumol, W. and Bowen, W. (1969) Performing Arts: The Economic Dilemma. Yale University, Massachusetts.

[14] Cwi, D (1980) Public Support of the Arts: Three Arguments Examined. Journal of Cultural Economics, 8, 39-62. https://doi.org/10.1007/BF02580849

[15] Frey, B. (2003) Public Support. In: Towse, R., Ed., A Handbook of Cultural Economics, Edward Elgar, Cleltenham, 389-398.

[16] Singh, A.P. (2017) Does FDI Promote Productivity? A Deep Dive. Indian Journal of Industrial Relations, 52, 443-455.

[17] Peacock, A. (1991) Economics, Cultural Values and Cultural Policies. Journal of 
Cultural Economics, 15, 1-18. https://doi.org/10.1007/BF00208443

[18] Porto (2007) Cultura para a política cultural. In: Rubim, A.A.C. and Barbalho, A., Eds., Políticasculturais no Brasil, EDUFBA, Salvador, 157-179.

[19] Valkama, P. and Bailey, S.J. (2001) Vouchers as an Alternative Public Sector Funding System. Public Policy and Administration, 116, 32-58. https://doi.org/10.1177/095207670101600103

[20] Towse, A. (2010) Textbook of Cultural Economics. Cambridge University Press, London. https://doi.org/10.1017/CBO9780511992131

[21] Peacock, A. (1994:1969) Welfare Economics and Public Subsidies to the Arts. Journal of Cultural Economics, 18, 151-161. https://doi.org/10.1007/BF01078938

[22] West, E.G. (1986) Arts Vouchers to Replace Grants. Economic Affairs, 6, 9-16. https://doi.org/10.1111/j.1468-0270.1986.tb01737.x

[23] Van Der Ploeg, F. (2006) The Making of Cultural Policy: A European Perspective. In: Ginsburgh, V.A. and Throsby, D., Eds., Handbook of the Economics of Art and Culture, 2nd Edition, North-Holland Elsevier, Oxford, 1183-1222. https://doi.org/10.1016/S1574-0676(06)01034-9

[24] Benhamou, F. (2007) A economia da cultura. Ateliê Editorial, Cotia.

[25] Brasil. Law no 12.761 (2012) Institui o Programa de Cultura do Trabalhador; cria o Vale-Cultura. Diário Oficial da União. Brasília.

[26] Brasil. Law n 12.527 (2011) Regula o acesso a informações. Diário Oficial da União. Brasília.

[27] Shimizu, J.K. and Domingues, E.P. (2011) Projeção de impactos econômicos do programa Minha Casa, Minha Vida: Uma abordagem de Equilíbrio Geral Computável. In: Encontro Nacional de Economia, Anais, ANPEC, Foz do Iguaçu, 39.

[28] Domingues, et al. (2015) Uma análise dos impactos econômicos e setoriais do programa Farmácia Popular do Brasil. Pesquisa e Planejamento Econômico. Rio de Janeiro, Vol. 45.

[29] Horridge, M.A. (2006) Generic Single-Country Computable General Equilibrium Model. Centre of Policy Studies and Impact Project, Monash University, Clayton.

[30] KPMG (2012) Economic Impact of the Victorian Arts and Cultural Sector, Australia.

[31] Dixon, P.B., Parmenter, B.R., Sutton, J. and Vincent, D.P. (1982) Orani: A Multisectoral Model of the Australian Economy.

[32] Dixon, P.B. and Rimmer, M.T. (2002) Dynamic General Equilibrium Modelling for Forecasting and Policy: A Practical Guide and Documentation of Monash. Elsevier, Amsterdam. https://doi.org/10.1108/S0573-8555(2001)256

[33] Domingues, et al. (2014) The World Financial Crisis in Brazil: Industry and Regional Economic Impacts. Journal of International Business and Economics, 2, 57-94. https://doi.org/10.15640/jibe.v2n3a4

[34] Domingues, et al. (2010) Repercussões setoriais e regionais da crise econômica de 2009 no Brasil: Simulações em um modelo de equilíbrio geral computável de dinâmica recursiva. CEDEPLAR/UFMG, Belo Horizonte.

[35] Souza, K. and Domingues, E. (2014) Mudanças no mercado de serviços domésticos: Uma análise da evolução dos salários no período 2006-2011. Economia Aplicada, 319-346. https://doi.org/10.1590/1413-8050/ea454

[36] Cardoso, D.F., Souza, K.B. and Domingues, E.P. (2014) Medidas recentes de de- 
soneração tributária no Brasil: Uma análise de equilíbrio geral computável, Juiz de Fora, Brazil.

[37] IBGE Instituto Brasileiro de Geografia e Economia (2008) Matriz de insumoproduto: Brasil, 2000/2005. IBGE, Rio de Janeiro.

[38] Tourinho, F., Kume, H. and Pedroso, A. (2007) Elasticidades de Armington para o Brasil: 1986-2002. Revista brasileira de economia, 61, 245-267. https://doi.org/10.1590/S0034-71402007000200006

[39] Almeida, A.N. (2011) Elasticidades renda e preços: Análise do consumo familiar a partir dos dados da POF 2008/2009. Texto de discussão Nereus, São Paulo.

[40] Harrison, W.J. and Pearson, K.R. (1994) Computing Solutions for Large General Equilibrium Models Using GEMPACK. The Centre of Policy Studies, Monach University, Clayton.

[41] Varian, H.R. (1992) Microeconomic Analysis. W. W. Norton \& Company, Nova York.

[42] Deaton, A. and Muelbauer, J. (1980) Economics and Consumer Behavior. Cambridge University Press, Cambridge. https://doi.org/10.1017/CBO9780511805653

[43] Hanslow, K.J. (2000) A General Welfare Decomposition for CGE Models. Center for Global Trade Analysis, Purdue University, West Lafayette. 


\section{Appendix: Stylized Equations of the BRIDGE Model}

\begin{tabular}{|c|c|c|}
\hline Number & Group & Dimension \\
\hline \multirow[t]{8}{*}{1} & Composition of industrial products and inputs & \\
\hline & $X 0(\mathrm{c}, 1, \mathrm{i})=X 1 \mathrm{TOT}(\mathrm{i}) \times \Psi_{0 \mathrm{cli}}\left(\mathrm{P}_{1}\right)$ & $\mathrm{N}_{\mathrm{c}} \mathrm{N}_{\mathrm{i}}$ \\
\hline & $X 0 \mathrm{COM}(\mathrm{c})=\Sigma_{\mathrm{i}} X 0(\mathrm{c}, 1, \mathrm{i})+\mathrm{A}(\mathrm{c})_{\mathrm{PF}}$ & $\mathrm{N}_{\mathrm{c}}$ \\
\hline & $X 1(\mathrm{c}, \mathrm{s}, \mathrm{i})=X 1 \mathrm{TOT}(\mathrm{i}) \times \Psi_{1 \mathrm{csi}}\left[\mathrm{P}_{1}(\mathrm{c}), \mathrm{P}_{2}(\mathrm{c}), \mathrm{A}_{\mathrm{li}}, \mathrm{A}_{\mathrm{TWIST}}\right]$ & $\mathrm{N}_{\mathrm{c}} \mathrm{N}_{\mathrm{s}} \mathrm{N}_{\mathrm{i}}$ \\
\hline & $\mathrm{L}(\mathrm{i})=X 1 \mathrm{TOT}(\mathrm{i}) \times \Psi_{\mathrm{Li}}\left[\mathrm{W}, \mathrm{Q}(\mathrm{i}), \mathrm{A}(\mathrm{i})_{\mathrm{PF}}\right]$ & $\mathrm{N}_{\mathrm{i}}$ \\
\hline & $\mathrm{K}(\mathrm{i})=X 1 \mathrm{TOT}(\mathrm{i}) \times \Psi_{\mathrm{Ki}}\left[\mathrm{W}, \mathrm{Q}(\mathrm{i}), \mathrm{A}(\mathrm{i})_{\mathrm{PF}}\right]$ & $\mathrm{N}_{\mathrm{i}}$ \\
\hline & $\mathrm{TOT}_{\mathrm{PFc}}=\Sigma_{\mathrm{c}} \mathrm{A}(\mathrm{c})_{\mathrm{PF}}$ & 1 \\
\hline & $\mathrm{TOT}_{\mathrm{PFi}}=\Sigma_{\mathrm{j}} \mathrm{A}(\mathrm{i})_{\mathrm{PF}}$ & 1 \\
\hline \multirow[t]{3}{*}{2} & Inputs for capital creation and asset prices & \\
\hline & $X 2(\mathrm{c}, \mathrm{s}, \mathrm{j})=X 2 \mathrm{TOT}(\mathrm{j}) \times \Psi 2_{\mathrm{cs}}\left[\mathrm{P}_{1}(\mathrm{c}), \mathrm{P}_{2}(\mathrm{c}), \mathrm{A}_{2 \mathrm{j}}, \mathrm{A}_{\mathrm{TWIST}}\right]$ & $\mathrm{N}_{\mathrm{c}} \mathrm{N}_{\mathrm{S}} \mathrm{N}_{\mathrm{i}}$ \\
\hline & $\mathrm{PI}(\mathrm{j})=\Psi_{\mathrm{PIj}}\left(\mathrm{P}_{1}, \mathrm{P}_{2}, \mathrm{~A}_{2 \mathrm{j}}\right)$ & $\mathrm{N}_{\mathrm{j}}$ \\
\hline \multirow[t]{4}{*}{3} & Demand for commodities by families & \\
\hline & $X 3(c, s)=\Psi_{3 c s}\left[C, P 3_{1}, P 3_{2}, A_{3}, A_{C / G D P}\right]$ & $\mathrm{N}_{\mathrm{c}} \mathrm{N}_{\mathrm{S}}$ \\
\hline & $X 3_{\mathrm{SUB}}(\mathrm{c})=\mathrm{q}_{\mathrm{H}} \times \mathrm{A} 3_{\mathrm{SUB}}(\mathrm{c})$ & $\mathrm{N}_{\mathrm{c}}$ \\
\hline & $X 3_{\text {LUX }}(\mathrm{c})=X 3_{-} \mathrm{S}(\mathrm{c})-X 3_{\mathrm{SUB}}$ & $\mathrm{N}_{\mathrm{c}}$ \\
\hline \multirow[t]{2}{*}{4} & Export & \\
\hline & $X 4(\mathrm{c})=\Psi_{4 i}[\mathrm{PE}(\mathrm{c})]+\mathrm{A}_{4}(\mathrm{c})$ & $\mathrm{N}_{\mathrm{c}}$ \\
\hline \multirow[t]{3}{*}{5} & Government demand & \\
\hline & $X 5(c, s)=A_{5}(c, s) \times A_{5 T O T}$ & $\mathrm{~N}_{\mathrm{c}} \mathrm{N}_{\mathrm{S}}$ \\
\hline & $\mathrm{A} 5_{\mathrm{TOT}}=\mathrm{C} \times \mathrm{A} 5_{\mathrm{TOT} 2}$ & 1 \\
\hline \multirow[t]{2}{*}{6} & Demand for margin services & \\
\hline & $X 3 \operatorname{MAR}(\mathrm{c}, \mathrm{s}, \mathrm{m})=\mathrm{A} 3 \operatorname{MAR}(\mathrm{c}, \mathrm{s}, \mathrm{m}) \times X 3(\mathrm{c}, \mathrm{s})$ & $\mathrm{N}_{\mathrm{c}} \mathrm{N}_{\mathrm{s}} \mathrm{N}_{\mathrm{m}}$ \\
\hline \multirow[t]{4}{*}{7} & Import and zero profit condition & \\
\hline & $\begin{array}{l}X 0 \operatorname{COM}(\mathrm{c})=\Sigma_{\mathrm{i}} X 1(\mathrm{c}, 1, \mathrm{i})+\Sigma_{\mathrm{i}} X 2(\mathrm{c}, 1, \mathrm{i})+X 3(\mathrm{c}, 1)+X 4(\mathrm{c})+ \\
X 5(\mathrm{c}, 1)+\sum_{\mathrm{c}} \sum_{\mathrm{s}} \Sigma_{\mathrm{m}} X 3 \operatorname{MAR}(\mathrm{c}, \mathrm{s}, \mathrm{m})\end{array}$ & $\mathrm{N}_{\mathrm{c}}$ \\
\hline & $X 0 \operatorname{IMP}(\mathrm{c})=\Sigma_{\mathrm{i}} X 1(\mathrm{c}, 2, \mathrm{i})+\Sigma_{\mathrm{i}} X 2(\mathrm{c}, 2, \mathrm{i})+{ }_{\mathrm{i}} X 3(\mathrm{c}, 2)+X 5(\mathrm{c}, 2)$ & $\mathrm{N}_{\mathrm{c}}$ \\
\hline & $\Sigma_{c} \mathrm{P}_{1}(\mathrm{c}) X 0(\mathrm{c}, 1, \mathrm{j})=\Sigma_{\mathrm{c}} \Sigma_{\mathrm{S}} \mathrm{P}_{\mathrm{s}}(\mathrm{i}) X \mathrm{l}(\mathrm{c}, \mathrm{s}, \mathrm{j})+\mathrm{W} \times \mathrm{L}(\mathrm{j})+\mathrm{Q}(\mathrm{j}) \times \mathrm{K}(\mathrm{j})$ & $\mathrm{N}_{\mathrm{i}}$ \\
\hline \multirow[t]{2}{*}{8} & Indirect Taxes & \\
\hline & $\mathrm{T} 4(\mathrm{c})=\mathrm{A}_{\mathrm{OT}}(\mathrm{c}) \times \mathrm{A}_{4 \mathrm{~T}}(\mathrm{c})$ & $\mathrm{N}_{\mathrm{c}}$ \\
\hline \multirow[t]{7}{*}{9} & Macroeconomic Variables & \\
\hline & $\mathrm{CPI}=\Psi_{\mathrm{CPI}}\left(\mathrm{P} 3_{1}, \mathrm{P} 3_{2}\right)$ & 1 \\
\hline & $\mathrm{WR}=(\mathrm{W} / \mathrm{CPI}) \times \mathrm{A}_{\mathrm{WR}}$ & 1 \\
\hline & $\mathrm{LTOT}=\Sigma_{\mathrm{j}} \mathrm{L}(\mathrm{j})$ & 1 \\
\hline & $\mathrm{KTOT}=\Sigma_{\mathrm{j}} \mathrm{K}(\mathrm{j})$ & 1 \\
\hline & $\begin{array}{l}\mathrm{GDP}_{\text {expenditure }}=\mathrm{C}+X 2 \mathrm{TOT} \_\mathrm{i} \times \Sigma_{\mathrm{j}} \mathrm{PI}(\mathrm{j})+X 5 \mathrm{TOT} \times \Sigma_{\mathrm{i}} \mathrm{P}_{\mathrm{S}}(\mathrm{i})+ \\
\Sigma \mathrm{i}[\mathrm{PE} / \Phi] \times X 4(\mathrm{i})-\Sigma_{\mathrm{i}}[\mathrm{PM} / \Phi] \times X 0 \mathrm{IMP}(\mathrm{i})\end{array}$ & 1 \\
\hline & $\begin{array}{l}\mathrm{GDP}_{\text {income }}=\mathrm{W} \times \mathrm{L}(\mathrm{j})+\mathrm{Q}(\mathrm{j}) \times \mathrm{K}(\mathrm{j})+\mathrm{A}(\mathrm{i})_{\mathrm{PF}} \\
\mathrm{GDP}_{\text {income }}=\mathrm{GDP}_{\text {expense }}\end{array}$ & 1 \\
\hline \multirow[t]{4}{*}{10} & Decomposition of changes in production & \\
\hline & $\begin{array}{l}\operatorname{INITSALES}(\mathrm{c}) \times \operatorname{DECOMP}(\mathrm{c}, \text { "localMarket" })=\operatorname{DOMSALES}(\mathrm{c}) \times \\
0 \operatorname{loc}(\mathrm{c})\end{array}$ & $\mathrm{N}_{\mathrm{c}}$ \\
\hline & $\begin{array}{l}\operatorname{INITSALES}(c) \times \operatorname{DECOMP}(c, \text { "DomShare" })=\text { DOMSALES }(c) \times \\
0 \operatorname{loc}(\mathrm{c}) / \operatorname{sdom}(\mathrm{c})\end{array}$ & $\mathrm{N}_{\mathrm{c}}$ \\
\hline & $\operatorname{INITSALES}(\mathrm{c}) \times \operatorname{DECOMP}(\mathrm{c}$, "Export") $=\mathrm{V} 4 \mathrm{BAS}(\mathrm{c}) \times X 4(\mathrm{c})$ & $\mathrm{N}_{\mathrm{c}}$ \\
\hline
\end{tabular}




\section{Continued}

\begin{tabular}{|c|c|}
\hline Sets & \\
\hline $\mathrm{i}$ & Industry \\
\hline c & Commodities \\
\hline s & Source of input: $s=($ domestic, imported $)=($ dom, $\mathrm{imp})$ \\
\hline \multicolumn{2}{|l|}{ Variáveis } \\
\hline$A(i)_{L}$ & Technological change in the use of labor by industry \\
\hline $\mathrm{A}(\mathrm{i})_{\mathrm{PF}}$ & Technological change in the use of primary factors by industry \\
\hline $\mathrm{A}_{0 \mathrm{~T}}(\mathrm{c})$ & Displacement in tariff power for all users \\
\hline$A_{1}$ & Technological change in the use of intermediate inputs \\
\hline $\mathrm{A}_{2}$ & Technological change in the use of inputs for investment \\
\hline$A_{3}(c, h)$ & Changes in preferences of family $h$ \\
\hline $\mathrm{A}_{3 \mathrm{SUB}}(\mathrm{c}, \mathrm{h})$ & Changes in preferences in the consumption of subsistence goods \\
\hline $\mathrm{A}_{4}(\mathrm{c})$ & Changes in external demand for domestic commodities \\
\hline $\mathrm{A}_{4 \mathrm{~T}}(\mathrm{c})$ & Shift in the power of export tariffs \\
\hline $\mathrm{A}_{5}(\mathrm{c}, \mathrm{s})$ & Exogenous changes in the composition of government spending \\
\hline $\mathrm{A}_{5 \mathrm{TOT}}$ & Exogenous changes in total government spending \\
\hline $\mathrm{A}_{5 \mathrm{TOT2}}$ & Ratio between government and household consumption \\
\hline $\mathrm{A}_{\mathrm{C} / \mathrm{PIB}}$ & Change in consumption ratio over GDP \\
\hline $\mathrm{A}_{\mathrm{WR}}$ & Displacement in real salary \\
\hline $\mathrm{C}_{\mathrm{h}}$ & Total consumption of family $h$ \\
\hline $\mathrm{P}_{1}$ & Domestic prices \\
\hline$P_{1 \text { dom }}(c)$ & Price of domestic commodity used as intermediate input \\
\hline $\mathrm{P}_{\text {limp }}(\mathrm{c})$ & Price of the imported commodity used as intermediate input \\
\hline $\mathrm{P}_{2 \mathrm{dom}}(\mathrm{c})$ & Prices of domestic commodities used for investment \\
\hline $\mathrm{P}_{2 \mathrm{imp}}(\mathrm{c})$ & Prices of imported commodities used for investment \\
\hline $\mathrm{P}_{3 \mathrm{imp}}$ & Prices of imported commodities used for consumption \\
\hline $\mathrm{P}_{3 \mathrm{dom}}$ & Prices of domestic commodities used for consumption \\
\hline $\mathrm{PIB}_{\text {despesa }}$ & GDP on the expenditure side \\
\hline $\mathrm{PIB}_{\text {renda }}$ & GDP on the income side \\
\hline$X 3_{\text {LUX }}(c, h)$ & Portion destined to the consumption of luxury goods by family \\
\hline$X 3_{\mathrm{SUB}}(\mathrm{c}, \mathrm{h})$ & Portion intended for the consumption of subsistence goods by family \\
\hline $\mathrm{A} 3_{\mathrm{MAR}}(\mathrm{c}, \mathrm{s}, \mathrm{m})$ & Technological changes in the supply of margins for families \\
\hline IPC & Consumer price index \\
\hline $\mathrm{K}(\mathrm{i})$ & Total capital employed in industry i \\
\hline KTOT & Total capital stock \\
\hline $\mathrm{L}(\mathrm{i})$ & Total work in industry $\mathrm{i}$ \\
\hline LTOT & Total employment \\
\hline $\mathrm{PE}(\mathrm{c})$ & Price of foreign currency for exports \\
\hline
\end{tabular}

h. Elaborated based on simulation results. 